\title{
EDUKASI CARA CUCI HIDUNG YANG BAIK SEBAGAI UPAYA PENCEGAHAN DARI PENULARAN COVID-19
}

\section{Education of Nose Washing and Treatment as an infection preventif from Covid-19}

\author{
Eka Arie Yuliyani ${ }^{1 *}$, Rika Hastuti $\mathrm{S}^{2}$, Eva Triani ${ }^{3}$, Indana Eva Ajmala ${ }^{4}$, Nurul Imaniaty As- \\ syarifiah $^{5}$, Mochamad Fauzi Aulia Akbar ${ }^{5}$ \\ ${ }^{1}$ Bagian THT-KL Fakultas Kedokteran Universitas Mataram, ${ }^{2}$ Bagian Ilmu Kesehatan \\ Masyarakat Fakultas Kedokteran Universitas Mataram, ${ }^{3}$ Bagian Parasitologi Fakultas \\ Kedokteran Universitas Mataram, ${ }^{4}$ Bagian Paru Fakultas Kedokteran Universitas \\ Mataram, ${ }^{5}$ Fakultas Kedokteran Universitas Mataram
}

\section{Jl. Pendidikan Nomor 37, Kota Mataram 83125, Nusa Tenggara Barat}

*Alamat korespondensi : yuliyani.eka@gmail.com

(Tanggal Submission: 10 Desember 2021, Tanggal Accepted : 31 Desember 2021)

Kata Kunci : Abstrak :

Edukasi cuci Di era pandemi, menjaga kesehatan rongga hidung dan mulut menjadi hal hidung, Pencegahan yang penting karena merupakan pintu masuk utama infeksi Covid-19. Cuci dan hidung merupakan suatu metode sederhana, ekonomis, serta layak penularan, rongga hidung dari mediator inflamasi dan mikroorganisme dan juga Covid-19 memiliki kemampuan dalam menurunkan jumlah virus didalam rongga hidung. Strategi edukasi kepada masyarakat berupa video merupakan pilihan di masa pandemi ini, sehingga lebih mudah diakses dan memberikan pemahaman lebih baik. Video cuci hidung ini disajikan dengan tujuan untuk memberikan pemahaman lebih baik mengenai tindakan cuci hidung, manfaat serta teknik melakukannya dengan baik dan benar sehingga mampu dipraktekkan oleh masyarakat dalam kehidupan sehari-hari. Video edukasi cuci hidung yang berdurasi pendek ini disosialisasikan kepada pasien dan nakes di RS UNRAM berjumlah 30 orang melalui link google drive yang diberikan oleh tim pengabdian, dengan kriteria usia minimal18 tahun, kooperatif serta bersedia menonton dan mengisi kuesioner dalam google form. Hasil survey digunakan untuk memantau umpan balik penonton, sebagai evaluasi terhadap pengembangan video edukasi selanjutnya. Berdasarkan hasil survey didapatkan data bahwa setelah menonton video, pemahaman responden terhadap isi pesan yang disampaikan di dalam video edukasi sekitar 93\% dan kebermanfaatan video edukasi sekitar 93,33\%. Hasil ini menggambarkan bahwa video edukasi cuci hidung ini dapat diterima oleh masyarakat dengan baik sebagai salah satu media edukasi. Melalui kegiatan 
pengabdian ini diketahui bahwa video edukasi cuci hidung dinilai dapat diterima oleh masyarakat dengan baik dan dapat memberikan pengetahuan, pemahaman serta manfaat cuci hidung, termasuk teknik melakukannya dengan baik dan benar untuk menjaga kesehatan rongga hidung.

Panduan sitasi / Citation guidance (APPA $7^{\text {th }}$ edition) :

Yuliyani, E. A., Hastuti, R., Triani, E., Ajmala, I. E., As-syarifiah, N. I., \& Akbar, M. F. A. (2021). Edukasi Cara Cuci Hidung Yang Baik Sebagai Upaya Pencegahan Dari Penularan Covid-19. Abdi Insani, 8 (3), 359-364. http://doi.org/10.29303/abdiinsani.v8i3.449

\section{PENDAHULUAN}

Berbagai upaya telah dilakukan oleh pemerintah untuk memutus rantai penyebaran covid-19 di masa pandemi ini. Mematuhi prokes dan menjaga kesehatanpun menjadi tuntutan masyarakat dalam melaksanakan semua aktifitas. Penyebaran informasi mengenai cara menjaga kesehatan sangat gencar dilakukan melalui berbagai hal seperti berita, majalah hingga sosial media tak luput dari kegiatan ini (Munadi, 2013). Kemajuan teknologi dan media komunikasi di era revolusi pengetahuan saat ini memberikan arti bagi pengembangan Pendidikan dimana informasi mengenai berbagai hal dapat diakses dengan cepat termasuk informasi tentang kesehatan (Kadriyan, 2019).

Salah satu pengembangan edukasi yg dinilai efektif untuk membantu proses pemahaman seseorang terhadap sesuatu yaitu melalui video edukasi. Video adalah media atau alat bantu edukasi yang dapat menampilkan kembali pesan-pesan dan gerakan-gerakan menggunakan efek tertentu, sehingga mampu menarik perhatian penonton serta memperkokoh proses pembelajaran ((Melina et al., (2014), Fadhilla, (2014)). Hal inilah yang menarik minat banyak pihak untuk melakukan edukasi melalui video, termasuk para tenaga kesehatan. Berbagai edukasi kesehatan dilakukan kepada masyarakat melalui media ini dengan harapan pesan yang disampaikan dalam video edukasi akan lebih mudah dipahami, salah satunya yaitu video edukasi cuci hidung ini.

Cuci hidung menjadi sesuatu hal yang sering diperbincangkan di masa pandemi ini, karena tindakan ini merupakan suatu cara untuk menjaga kesehatan dan kebersihan rongga hidung dari berbagai mikroorganisme seperti bakteri, virus, allergen dan juga mediator inflamasi. Menjaga kebersihan rongga hidung dan mulut menjadi hal yang paling penting mengingat rongga hidung dan mulut merupakan salah satu jalan masuk utama virus covid-19 (Casale et al., 2020). Sindrom pernapasan akut coronavirus 2 atau yang lebih dikenal sebagai SARS-CoV-2 merupakan penyebab penyakit coronavirus-2019 dan telah menyebar kelebih dari 200 negara serta mencapai status pandemi (Gugus Tugas Percepatan Penanganan COVID-19, 2021).

Sejak ribuan tahun yang lalu, cuci hidung merupakan bagian dari Hatha Yoga yaitu suatu metode yang telah dikenal dan banyak dipraktekkan. Kemudian pada tahun 1931 oleh Proetz, metode dan larutan cuci hidung pertama kali dijelaskan dalam sebuah buku yang hingga saat ini cuci hidung direkomendasikan untuk mengatasi berbagai keluhan sinonasal (Heatley, 2011). Penggunaan cairan salin isotonis maupun hipertonis sebagai pencuci hidung pada pasien yang memiliki gangguan hidung, dapat membantu mempercepat proses perbaikan klinis, karena tindakan cuci hidung ini dapat memperbaiki fungsi mukosiliar hidung, menurunkan mediator inflamasi, membersihkan sekret dan mengurangi edema mukosa (Van den Berg et al., 2014). Selain fungsi di atas, cuci hidung juga memiliki kemampuan dalam menurunkan jumlah virus di dalam rongga hidung (Casale et al., 2020).

Berdasarkan hal ini lah sosialisasi mengenai tindakan cuci hidung ini sangat diperlukan. Video cuci hidung ini disajikan dengan tujuan untuk memberikan pemahaman yang lebih baik mengenai 
tindakan cuci hidung, manfaat serta teknik melakukannya dengan baik dan benar sehingga mampu dipraktekkan oleh masyarakat dalam kehidupan sehari-hari untuk menjaga kesehatan rongga hidung.

\section{METODE KEGIATAN}

Kegiatan pengabdian masyarakat ini dilakukan dengan menggunakan video edukasi cuci hidung yang dibuat secara bersama-sama oleh tim pengabdian dan Dokter Muda Fakultas Kedokteran Universitas Mataram dengan melalui serangkaian editing sehingga diperoleh video yang menarik dan layak untuk disosialisasikan kepada masyarakat. Video ini berdurasi pendek yaitu 5-6 menit yang dilengkapi dengan gabungan antara gambar alamiah dan beberapa gambar animasi serta tulisan yang diharapkan dapat memperjelas maksud atau pesan yang ingin disampaikan. Dalam video ini berisikan informasi mengenai tindakan cuci hidung, manfaatnya serta teknik melakukannya dengan baik dan benar. Selain itu dijelaskan pula tentang bahan dan alat yang digunakan sehingga setelah menonton video edukasi tersebut, masyarakat akan dipandu untuk dapat mempraktekkannya.

Pemilihan metode edukasi menggunakan video pada kegiatan pengabdian ini adalah berdasarkan beberapa penelitian yang menyatakan bahwa metode ini dinilai efektif sebagai media pembelajaran untuk membantu seseorang memahami sesuatu hal. Sosialisasi dilakukan kepada responden yang terdiri dari pasien dan Nakes di RS UNRAM berjumlah 30 orang melalui link google drive yang diberikan oleh tim pengabdian, dengan kriteria usia minimal18 tahun, kooperatif serta bersedia menonton dan mengisi kuesioner dalam google form. Hasil survey digunakan untuk memantau umpan balik penonton, sebagai evaluasi terhadap pengembangan video edukasi selanjutnya

\section{HASIL DAN PEMBAHASAN}

Video edukasi tentang cuci hidung ini disosialisasikan oleh Tim pengabdian FK Unram dengan maksud agar masyarakat lebih memahami dan menyadari pentingnya melakukan tindakan ini dalam hal menjaga kesehatan dan kebersihan rongga hidung. Video edukasi ini diharapkan menjadi salah satu media yang akan diakses dan dipergunakan masyarakat untuk memperoleh pengetahuan mengenai cuci hidung, manfaat serta teknik melakukannya dengan baik dan benar.

Seperti yang telah dijelaskan di atas bahwa cuci hidung merupakan metode yang dinilai praktis dan sederhana sebagai usaha untuk menjaga kesehatan rongga hidung dalam kehidupan sehari-hari. Banyak penelitian menyebutkan bahwa tindakan cuci hidung ini sangat diterima dengan baik dan dapat membantu memperbaiki kualitas hidup tanpa efek yang menyakitkan (Suh \& David, 2011). Cuci hidung dengan salin isotonis dapat membantu menjaga kebersihan rongga hidung dari infeksi berbagai mikroorganisme dan mediator radang termasuk kemampuannya dalam menurunkan jumlah virus di dalam rongga hidung. Larutan salin isotonis merupakan larutan yang paling fisiologis untuk epitel hidung sehingga aman dan nyaman digunakan sebagai pembilas berbagai iritan dan allergen yang terdapat di dalam rongga hidung (Hendradewi et al., 2016).

Cuci hidung dapat dilakukan dengan teknik menyemprotkan salin isotonis menggunakan spuit $10 \mathrm{cc} / 20 \mathrm{cc}$ ke dalam rongga hidung kanan dan kiri secara bergantian. Hal pertama yang dilakukan pada prosedur cuci hidung yaitu menyiapkan semua peralatan yang digunakan seperti spuit $10 \mathrm{ml} / 20 \mathrm{ml}$, transofix/gunting, larutan salin isotonis atau $\mathrm{NaCl} 0,9 \% 500 \mathrm{cc}$, wadah penampungan air dan tissue. Setelah itu tuangkan larutan salin $\mathrm{NaCl} 0,9 \%$ secukupnya ke dalam wadah penampungan air yang bersih, kemudian buka spuit $10 \mathrm{ml} / 20 \mathrm{ml}$ yang masih steril dan sedot air ke dalam spuit. Selanjutnya posisikan kepala menunduk dengan kepala sedikit menoleh ke hidung yang akan disemprot kurang lebih sekitar $45^{\circ}$, mulut agak dibuka. Masukkan ujung spuit ke dalam lubang hidung yang akan 
disemprot. Selama penyemprotan, pasien disarankan untuk menahan nafas sesaat untuk mencegah aspirasi atau tersedak. Kemudian semprotkan spuit yang telah terisi larutan salin isotonis $\mathrm{NaCl} 0,9 \%$ dengan cepat ke dalam rongga hidung sisi yang berlawanan, begitu pula sebaliknya.

Berdasarkan penelitian oleh Perera et al., (2017), pesan eduklasi yang disampaikan secara online tidak digunakan hanya pada bidang teknologi informasi saja, tetapi bidang lain seperti kesehatanpun dapat juga menggunakannya. Menurut Igiany et al., (2016), pemberian informasi melalui video dapat lebih mudah dipahami dan dapat ditayangkan berulang-ulang sehingga dinilai efektif untuk mengubah pandangan objek yang akan diintervensi. Media edukasi dengan menggunakan video melibatkan semua alat indera untuk mengolah informasi. Pendengaran dan penglihatan objek sasaran sangat diandalkan pada media video. Isi pesan atau informasi yang disampaikan kemungkinan dapat lebih mudah dimengerti dan diingat, karena adanya efek gambar yang bergerak dan suara dapat mempermudah seseorang untuk memahami sesuatu yang dapat meningkatkan pengetahuan (Maulana \& Heri, 2009).

Pada video edukasi cuci hidung ini pun menggabungkan antara audio dan visual yang dibuat sedemikian rupa sehingga mampu membantu masyarakat untuk lebih mudah memahami pesan yang disampaikan. Video edukasi cuci hidung dapat dilihat pada : https://drive.google.com/file/d/1guEnLBmA SmasB8QS4f-R6VMA2PtdByd/view?usp=sharing yang terdapat dalam google drive. Tampilan beberapa cuplikan video edukasi dapat dilihat pada Gambar 1 di bawah ini.
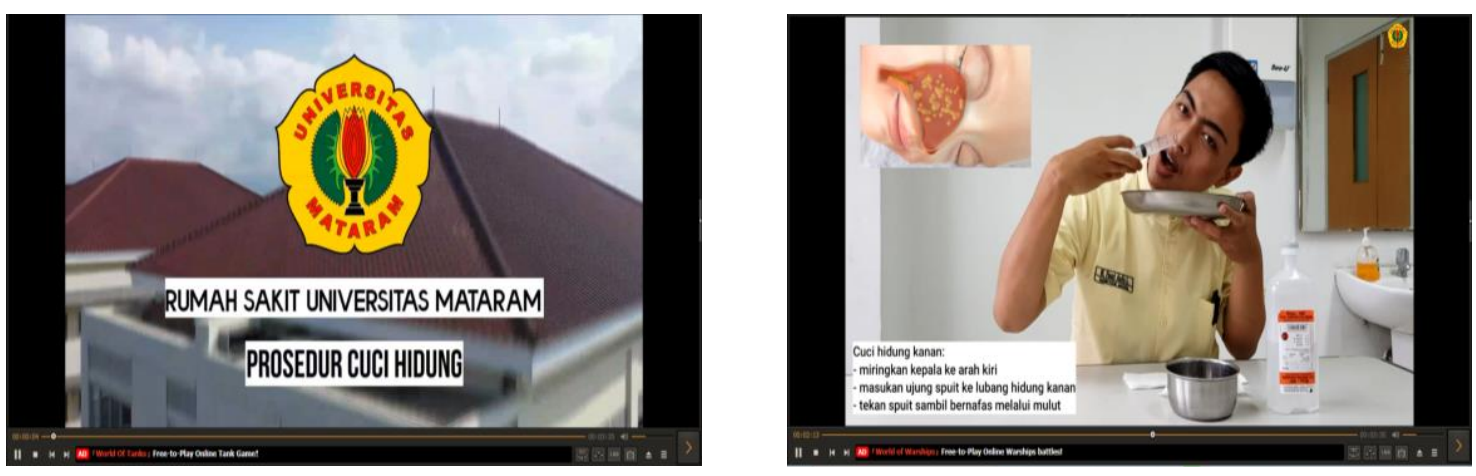

Gambar 1. Tampilan video edukasi cuci hidung

Setelah menonton video, masyarakat diminta untuk mengisi kuesioner yang berisikan beberapa pertanyaan sederhana mengenai pengetahuan dan kebermanfaatan video edukasi, dimana kuesioner tersebut diberikan melalui link google form : https://forms.gle/vRgZ2rnSzxZ76okF7 seperti yang terlihat di gambar 2 . Selanjutnya setiap jawaban yang ada akan dianalisis dan digunakan sebagai umpan balik dan evaluasi serta perbaikan mutu video di masa yang akan datang. 


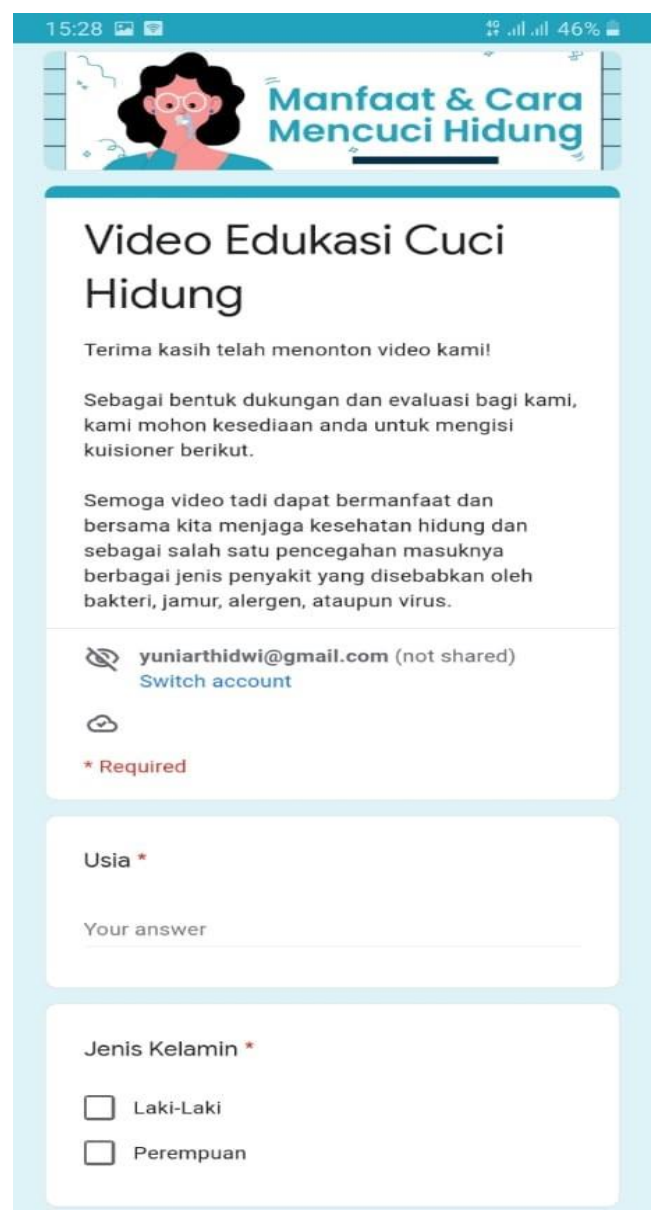

Gambar 2. Tampilan google form kuesioner video cuci hidung

Data yang diperoleh dari hasil survey pada 30 responden mengenai video edukasi setelah dianalisis secara deskriptif yaitu bahwa pemahaman responden terhadap isi pesan yang disampaikan di dalam video edukasi sekitar 93\% dan kebermanfaatan video edukasi sekitar 93,33\%. Data ini menggambarkan bahwa video edukasi cuci hidung ini dapat diterima dengan baik oleh responden sebagai media edukasi dan dapat dikembangkan lebih baik lagi sehingga nilai kebermanfaatan dan pengetahuan yang disampaikan di dalam video semakin baik.

Menurut McNab dan Skapetis (2019), seperti yang dikutip oleh Hamsu, K,dkk (2019) menyarankan bahwa video edukasi sebaiknya ditayangkan secara terus menerus di ruang tunggu pasien. Keunggulan video sebagai media belajar juga ditunjukkan oleh Batubara \& Ariani (2016), dalam penelitiannya dimana video edukasi dikatakan mampu menjelaskan konten lebih nyata serta lebih mudah digunakan.

\section{KESIMPULAN DAN SARAN}

Melalui kegiatan pengabdian ini diketahui bahwa video edukasi cuci hidung dinilai dapat diterima oleh masyarakat dengan baik dan dapat memberikan pengetahuan, pemahaman serta manfaat cuci hidung, termasuk teknik melakukannya dengan baik dan benar untuk menjaga kesehatan rongga hidung. Berdasarkan data deskriptif bahwa setelah menonton video pemahaman responden terhadap isi pesan yang disampaikan di dalam video edukasi sekitar $93 \%$ dan kebermanfaatan video edukasi sekitar 93,33\%. Diharapkan video cuci hidung dapat menjadi media yang dipilih masyarakat dan tindakan cuci hidung dapat dikenal serta diterapkan oleh masyarakat untuk menjaga kesehatan hidung dalam kehidupan sehari-hari. 


\section{UCAPAN TERIMA KASIH}

Ucapan terima kasih diberikan penulis kepada para peserta pengabdian yaitu pasien dan nakes di RS UNRAM, Teman Sejawat, Dokter Muda serta seluruh pihak yang telah membantu dalam pelaksanaan kegiatan pengabdian ini, dan juga Bagian THT-KL RS UNRAM atas ijin dan dukungannya pada kegiatan pengabdian masyarakat ini. Terima kasih pula kepada Lembaga Penelitian dan Pengabdian Kepada Mayarakat (LPPM) Universitas Mataram atas dukungan financialnya.

\section{DAFTAR PUSTAKA}

Batubara, H. H., \& Ariani, D. N. (2016). Pemanfaatan Video sebagai Media Pembelajaran Matematika SD/MI. Muallimuna Jurnal Madrasah Ibtidaiyah, 2(1), 47-66.

Casale, M., Vittorio, R., Lorenzo, S., Antonio, M., \& Massimo, C. (2020). Could nasal irrigation an oral rinse reduce the risk for COVID-19 infection? International Journal of Immunopathology and Pharmacology, 34, 1-3.

Fadhilla, H. N. (2014). Pengaruh Penyuluhan Cuci Tangan menggunakan Media Video terhadap Keterampilan Cuci Tangan pada Siswa Sekolah Dasar [thesis]. Universitas Sebelas Maret, Surakarta.

Gugus Tugas Percepatan Penanganan COVID-19. (2021). Covid-19. https://covid19.go.id/

Heatley, D. G. (2011). The Safety and Efficacy of Nasal Saline Irrigation. Madison: The OtolaryngologyHead and Neck Surgery. Winconsin (US) : School of Medicine, University of Wincosin.

Hendradewi, S., Novi, P., \& Nurmala, S. (2016). Perbedaan transport mukosiliar pada pemberian larutan garam hipertonik dan isotonik penderita rinosinusitis kronis. ORLI, 46(2), 12-18.

Igiany, P. D., Sudargo, T., \& Widyatama, R. (2016). Efektivitas penggunaan video dan buku bergambar dalam meningkatkan pengetahuan, sikap, dan keterampilan ibu mencuci tangan memakai sabun. Berita Kedokteran Masyarakat, 32(3), 89-94.

Kadriyan, H. (2019). Pelayanan kesehatan Telinga Hidung Tenggorok Kepala dan Leher pada Masa Revolusi Industri 4.0: Refleksi dan Studi Kasus di NTB, Ed.1. Mataram (ID) : Mataram University Press.

Maulana, H., \& Heri, D. J. (2009). Promosi Kesehatan. Jakarta (ID) : EGC.

Melina, F., Soebiyanto, A. A., \& Wujuso, H. (2014). Perbedaan Media Pembelajaran ( Leaflet Dan Video ) Terhadap Keterampilan Sadari Ditinjau Dari Motivasi. Jurnal Kesehatan Samodra IImu, 5(2), 116-125.

Munadi, Y. (2013). Media Pembelajaran Sebuah Pendekatan Baru. Jakarta (ID) : GP.

Perera, V., Mead, C., Buxner, S., Lopatto, D., Horodyskyj, L., Semken, S., \& Anbar, A. D. (2017). Students in fully online programs report more positive attitudes toward science than students in traditional, in-person programs. CBE-Life Sciences Education, 16(4), 60.

Suh, J. D., \& David, W. K. (2011). Treatment Option for Chronic Rhinosinusitis. Proceedings of The American Thoracic Society, 132-140.

Van den Berg, J. W. G., Linden, M. d. N., Nina, M. K., Anne, G. M. S., Roderick, P. V, \& Wilko, G. (2014). Limited Evidence: Higher Efficacy of Nasal Saline Irrigation over Nasal Saline Spray in Chronic Rhinosinusitis-An Update and Reanalysis of the Evidence Base. American Academy of Otolaryngology-Head and Neck Surgery, 150(1), 16-21. 